\title{
Comparative Study of the Protective Effects of Taurine and Melatonin on Cytochrome P450 2E1 and some Oxidative Stress Markers in Streptozotocin-induced Diabetic Rats
}

\author{
Manal El-Batch, Azza M. Hassan*, Heba A. Mahmoud** \\ Medical Biochemistry, Microbiology \& Immunlogy* and \\ Pharmacology** Departments, Faculty of Medicine, Tanta University
}

\begin{abstract}
Melatonin and taurine have alleviative effects in streptozotocin (STZ)-induced diabetic rats. Male Wistar rats were divided into non-diabetic, diabetic, diabetic melatonin (administered at $200 \mu \mathrm{g} / \mathrm{kg} /$ day dissolved in $0.5 \mathrm{ml}$ of normal saline) and diabetic taurine (administered at $2 \%$ in the drinking water) supplemented groups. At the end of the study, blood was collected and used for determination of glucose, total cholesterol, triglyceride levels, liver enzymes (ALT and AST), $\beta$-hydroxybutyrate ( $\beta$ $H B)$, in addition to advanced oxidation protein product (AOPP) level, and paraoxonase (PON1) enzyme activity. Also, liver tissue was examined for malondialdhyde (MDA) level, glutathione peroxidase (GPx) enzyme activity and cytochrome P450 2E1 (CYP2E1) both enzyme activity and gene expression. Light microscopy pictures of liver tissue were also evaluated for signs of its damage. An increased CYP2E1 activity and gene expression with a concomitant significant change in oxidative stress parameters were found in STZ-induced diabetic rats, suggesting the possible diabetes-induced injury. Taurine or melatonin supplementation to the diabetic rats alleviated these experimental parameters with more significant effect for taurine than that of melatonin. Suppression of $\beta-H B$ production by taurine can be one of the mechanisms of reduction in CYP2E1. Conclusion: Taurine has the capabilities more than melatonin in protecting the liver from the hepatic injury induced by type 1 diabetes, by reducing the oxidative stress and restoring CYP2E1 activity and gene expression, suggesting hepatic protective nature of taurine in diabetic rats. Therefore antioxidants might prove beneficial as an adjuvant treatment to insulin in type 1 diabetes associated with manifestations of liver injury.
\end{abstract}

\section{INTRODUCTION}

Oxidative stress is involved in the etiology and pathogenesis of many diabetic complications. ${ }^{(1)}$ Streptozotocin (STZ) injection in animals generates type 1 diabetes and produces various kinds of reactive oxygen species (ROS) that are either formed by STZ itself over the short term or resulted from the induced hyperglycemia. ${ }^{(2)}$

The increased oxidative stress, as measured by indices of elevated lipid peroxidation, oxidative modification products of proteins, depletion of 
endogenous antioxidant, and antioxidant enzyme activities in plasma and tissues, are commonly found in STZ-induced diabetic rats, and these alterations may cause tissues to be more susceptible to oxidative damage. The vulnerability of each tissue to oxidative stress can vary depending upon their expressed antioxidant enzymes. ${ }^{(3)}$

Liver is the focal organ of oxidative and detoxifying processes, as well as free radical reactions and the biomarkers of oxidative stress are elevated in the liver at an early stage in many diseases, including diabetes mellitus. ${ }^{(4)}$

Cytochrome P450 2E1 (CYP2E1) has been implicated in the generation of tissue damaging hydroxyl radicals in patients suffering from diabetes and liver diseases. ${ }^{(\mathbf{5 , 6})}$ Therefore, any agent with inhibitory effect on CYP2E1 activity may be able to alleviate such oxidative stress effects.

Several studies have recently dealt with either maintenance of antioxidant defense of diabetic liver or reduction of peroxidative stress induced hepatic damage in experimental models. ${ }^{(\mathbf{7}, \mathbf{8})}$ Hence, it is recommended that therapy with antioxidants may signify a useful pharmacologic overture to the management of diabetes complications .

The antioxidant role of taurine (2aminoethanesulfonic acid) has been attributed to its ability to scavenge ROS, to reduce the production of lipid peroxidation end products, and to stabilize biomembranes. ${ }^{(9)}$

Melatonin

(N-acetyl-5methoxytryptamine), a secretory product of the pineal gland, is a potent scavenger of hydroxyl and peroxyl radical that regulates the activity of anti-oxidant enzymes. Melatonin ameliorated carbon tetrachlorideinduced hepatic fibrogenesis in rats via inhibition of oxidative stress and proinflammatory production. ${ }^{(10)}$

cytokines

So, the aim of the present study was to compare between the effect of either taurine or melatonin on CYP2E1 activity, expression and some oxidative stress parameters in STZ-induced diabetes in rats, in order to elucidate their possible mechanisms on reducing hepatic insult in type 1 diabetes.

\section{MATERIALS \& METHODS}

\section{Chemicals}

Bio-chemicals and substrates were purchased from Sigma-Aldrich chemicals (St. Louis, MO). STZ (Trade name Zanosar) was in the form of $1 \mathrm{~g}$ vials. The treatment dose of taurine and melatonin was chosen according to Yao et al., ${ }^{(11)}$ and Montilla et al., ${ }^{(12)}$ respectively.

\section{Animals}

\subsection{Experimental animals and diets}

Forty male Wistar rats weighing approximately between 150 and $170 \mathrm{~g}$ were acclimatized under laboratory condition for 2 weeks prior to the experiments. They were maintained under standard conditions of temperature $\left(23 \pm 2{ }^{\circ} \mathrm{C}\right)$ with an alternating $12 \mathrm{~h}$ light/dark cycles and were allowed free access to food and water all times.

\subsection{Induction of diabetes}

Induction of diabetes was made by a single intraperitoneal injection of STZ at a dose of $70 \mathrm{mg} / \mathrm{kg}$ body 
weight in freshly prepared ice-cold citrate buffer $(0.1 \mathrm{M} \mathrm{pH} 4.0)$ for 3 consecutive days. STZ used to induce damage to pancreatic beta cells, exhibited massive glycosuria and hyperglycemia within 3 days. Diabetes was defined as a blood glucose level greater than $250 \mathrm{mg} / \mathrm{dl}^{(\mathbf{5})}$ using a drop of blood obtained by a tail-vein puncture monitored at different time intervals throughout the study using ACCUTREND reagent strips (Roche Diagnostics $\mathrm{GmbH}$, Germany).

\subsection{Animal treatment}

- After induction of diabetic state (within 72 hours after STZ injection), diabetic rats were divided into three groups with 10 rats in each group. One group was maintained on a standard diet (untreated-diabetes group; G-II), another one was injected by melatonin daily intraperitoneally three days prior to induction of diabetes in a dose of $200 \mu \mathrm{g} / \mathrm{kg} /$ day dissolved in $0.5 \mathrm{ml}$ of normal saline (melatonin -diabetic treated group; G-III), and the last group treated with $2 \%(\mathrm{w} / \mathrm{v})$ taurine in the drinking water which was made fresh daily (taurine -diabetic treated; G-IV), in addition to 10 rats received an intraperitoneal injection of a single dose of 0.1 $\mathrm{mol} / \mathrm{L}$ sodium citrate buffer $(\mathrm{pH}$ 4.5) (normal control group; G-I)

- The body weight, food, and water intake were monitored daily throughout the study period (4 weeks). Dead rats were excluded from the study.

- At the end of the experiment, after an overnight fast, the rats were decapitated then: o The blood was collected partly in plain tube to obtain serum and partly on $\mathrm{K}_{3}$ EDTA (tri-potassium ethylene diaminetetraacetic acid) coated tubes to obtain plasma, centrifuged at $3000 \mathrm{rpm}$ for 20 $\min$ at $4^{\circ} \mathrm{C}$, and used for determination of some biochemical analysis, mentioned later on

o The liver excised, washed with ice cold saline to remove extraneous materials, cut into four parts and used as follow:

\section{Liver homogenates}

Preparation of liver tissue homogenates

- First part of the liver ( $3 \mathrm{~g})$ minced and homogenized (potterElvenhjem tissue homogenizer) in $10 \mathrm{mM}$ potassium phosphate containing $1 \mathrm{mM}$ EDTA, $\mathrm{pH} 7.4$, and centrifuged at $12,000 \times \mathrm{g}$ for $30 \mathrm{~min}$ at $4{ }^{\circ} \mathrm{C}$. The resultant supernatant (free of insoluble materials), was collected, stored at $-80{ }^{\circ} \mathrm{C}$ and used for determination of malondialdehyde (MDA) level, glutathione peroxidase (GPx) enzyme activity and protein content.

- Second part of the liver was used for microsomes preparation as described elsewhere. ${ }^{(13)}$ It was homogenized in 4 vol.(w/v) of a $20 \mathrm{mM}$ Tris $/ \mathrm{HCl}, 150 \mathrm{mM} \mathrm{KCl}$ and $1 \mathrm{mM}$ EDTA solution $(\mathrm{pH}$ 7.6), with a Teflon pestle (PotterElvehjem, Inframo, Wayne, NJ), and centrifuged at $9000 \times \mathrm{g}$ for 20 min. The post-mitochondrial supernatant obtained was centrifuged at $105000 \times \mathrm{g}$ for 60 min. The pellet obtained was re- 
suspended in a $20 \mathrm{mM}$ Tris $/ \mathrm{HCl}$, $150 \mathrm{mM} \mathrm{KCl}$ and $3 \mathrm{mM} \mathrm{MgCl} 2$ solution ( $\mathrm{pH} 7.6)$ and centrifuged again at $105000 \mathrm{xg}$ for $60 \mathrm{~min}$ to obtain the final microsomal fraction. The microsomes were finally re-suspended in the Tris/ $\mathrm{HCl} / \mathrm{KCl} / \mathrm{MgCl}_{2}$ solution, containing $15 \%(\mathrm{v} / \mathrm{v})$ glycerol in water $(\mathrm{pH}$ 7.6), immediately stored at $-70{ }^{\circ} \mathrm{C}$ until used for determination of CYP2E1 activity. Centrifugation was performed using TL-100 Beckmann ultracentrifuge.

- Third part of the liver was used for determination of CYP2E1 expression as mentioned below.

- Fourth part was used for histopathological examination.

4. Biochemical analysis

4.1.1 Fasting plasma glucose level:

It was determined by glucose oxidase method using a commercial kit (Elitech Diagnostics Company, France) according to the manufacturer instructions.

\subsubsection{Total serum cholesterol and triglyceride levels:}

They were estimated using the appropriate kits (Boehringer Mannheim, Germany).

\subsubsection{Serum ALT and AST activities:}

$\begin{array}{clr}\text { They } & \text { were measured using } \\ \text { Randox } & \text { kits } & \text { according }\end{array}$ manufacturer instructions.

\subsubsection{Plasma $\beta$-HB concentration:}

It was determined using the kits purchased from Randox Laboratories (Antrum, UK) according to McGarry et al. ${ }^{(14)}$

\subsubsection{Plasma AOPP level:}

It was determined according to Witko-Sarsat et al. ${ }^{(\mathbf{1 5})}$ Briefly, AOPP were measured by spectrophotometry on a microplate reader and were calibrated with chloramine-T (Sigma, St. Louis, MO) solutions that in the presence of potassium iodide absorb at $340 \mathrm{~nm}$. In test wells, $200 \mu \mathrm{l}$ of plasma diluted $1 / 5$ in phosphate buffer saline (PBS) was placed on a 96-well microtiter plate, and $20 \mu \mathrm{l}$ of acetic acid was added. In standard wells, 10 $\mu \mathrm{l}$ of $1.16 \mathrm{M}$ potassium iodide (Sigma) was added to $200 \mu \mathrm{l}$ of chloramine-T solution $\quad(0-100$ $\mu \mathrm{mol} /$ liter) followed by $20 \mu \mathrm{l}$ of acetic acid. The absorbance of the reaction mixture is immediately read at 340 $\mathrm{nm}$ on the microplate reader against a blank containing $200 \mu \mathrm{l}$ of PBS, $10 \mu \mathrm{l}$ of potassium iodide, and $20 \mu \mathrm{l}$ of acetic acid. AOPP concentrations were expressed as micromoles per liter of chloramine- $\mathrm{T}$ equivalents ( $\mu \mathrm{mol} / 1)$

4.1.6 Serum PON1 enzyme activity:

It was measured by adding serum to Tris buffer $(100 \mathrm{mmol} / \mathrm{L}, \mathrm{pH} 8.0)$ containing $2 \mathrm{mmol} / \mathrm{L} \mathrm{CaCl}_{2}$ and 1 $\mathrm{mmol} / \mathrm{L}$ paraoxon (O,O-diethyl-Onitrophenylphosphate. The rate of generation of P-nitrophenol was determined at $405 \mathrm{~nm}, 25{ }^{\circ} \mathrm{C}$ with the use of Ultro spec 1000 (Pharmacia Biotech) spectrophotometer as described previously. (16)

\subsubsection{Liver tissue malondialdehyde} (MDA):

It was measured according to Halliwell \& Chirico, ${ }^{(17)}$ that depends on that MDA reacts with thiobarbituric acid (TBA) producing thiobarbituric acid reactive substance (TBARS), a pink chromogen, which can be measured spectrophotometrically at $532 \mathrm{~nm}$. MDA expressed as $\mathrm{nmol} / \mathrm{g}$ tissue and 
was calculated using $1.65 \times 105 \mathrm{M}^{-1}$ $\mathrm{cm}^{-1}$ as molar absorption coefficient.

\subsubsection{Liver tissue GPx activity:}

It was measured according to Flohe and Gunzler ${ }^{(18)}$ based on the coupling reaction with glutathione reductase (GR). The oxidized glutathione (GSSG) formed after reduction of hydroperoxide by GPx is recycled to its reduced state by GR in the presence of NADPH. The oxidation of NADPH is accompanied by a decrease in absorbance at 340 nm. One unit of GPx was defined as the amount of enzyme that catalyzes the oxidation of $1 \mathrm{nmol}$ of NADPH per minute at $25{ }^{\circ} \mathrm{C}$. The enzyme activity was calculated using a molar extinction coefficient for NADPH of 6.220 $\mathrm{M}^{-1} \mathrm{~cm}^{-1}$ and normalized to protein concentration and it was expressed as nanomoles of NADPH consumed per minute per milligram of protein.

\subsubsection{Hepatic microsomal CYP2E1} activity:

It

was estimated

spectrophotometrically by measuring the hydroxylation of $\mathrm{p}$-nitrophenol to produce $\mathrm{p}$-nitrocatechol according to Reinke and Moyer ${ }^{(19)}$. Briefly, 200 $\mu 1$ microsomes (equivalent to $1-2 \mathrm{mg}$ protein) were mixed with $0.2 \mathrm{mM}$ nitrophenol, $50 \mathrm{mM}$ Tris- $\mathrm{HCl}$ and 5 $\mathrm{mM} \mathrm{MgCl} 2$ ( $\mathrm{pH}$ 7.4). The reaction was performed at $37{ }^{\circ} \mathrm{C}$ and was started by the addition of $1 \mathrm{mM}$ NADPH. After $10 \mathrm{~min}$, the reaction was stopped with $0.5 \mathrm{ml}$ of $0.6 \mathrm{~N}$ perchloric acid. The precipitated proteins were removed by centrifugation at $3000 \mathrm{x}$ g for $5 \mathrm{~min}, 1$ $\mathrm{ml}$ of the supernatants was mixed with $100 \mu \mathrm{l}$ of $10 \mathrm{~N} \mathrm{NaOH}$ and absorbance was read at $510 \mathrm{~nm}$. An extinction coefficient of $9.53 \mathrm{mM}^{-1} \mathrm{~cm}^{-1}$ for $\mathrm{p}$ - nitrocatechol was used and the result was expressed as nanomoles of $\mathrm{p}$ nitrocatechol formed $/ \mathrm{min} / \mathrm{mg}$ protein.

\subsubsection{Protein content in tissue} homogenate:

It was determined by the Lowry method using bovine serum albumin as a standard. (20)

\section{2 Gene expression of cytochrome} P450 2E1

4.2.1. Preparation of Total Liver $R N A$

Total RNA was prepared from liver tissue according to the manufacture instructions (Promega). Approximately 100-200 mg of liver tissue was homogenized and subjected to RNA extraction to disrupt cells followed by denaturation of nucleoprotein complexes, inactivation of endogenous ribo nuclease (RNase) activity, and finally removal of proteins and DNA. The resulting RNA was reconstituted in diethylpyro carbonatetreated water $\left(\mathrm{DEPC}-\mathrm{H}_{2} \mathrm{O}\right)$, checked for purity and integrity spectrophotometrically at $260 \mathrm{~nm}$ and by gel electrophoresis and used for RTPCR

\subsubsection{RT-PCR for CYP2E1}

Reverse transcription of $10 \mu \mathrm{g}$ of RNA to a corresponding amount of cDNA was carried out according to the manufacture instructions (Promega, USA) and stored at $-20^{\circ}$ until use. Amplification of cDNA and the selection of the primer sequences were done according to Yang and Raner. (21) The PCR reactions of cDNA were performed in a final volume of $50 \mu \mathrm{l}$ consisting of $5 \mu \mathrm{l}$ cDNA, $5 \mu \mathrm{l} 10 \mathrm{X}$ PCR buffer, $200 \mu \mathrm{M}$ of each deoxynucleotide triphosphate, $2.5 \mathrm{mM}$ $\mathrm{MgCl} 2, \quad 1.5 \mathrm{U}$ AmpliTaq DNA polymerase (Promega,USA) and 50 
pmol each of the following CYP2E1 specific forward and reverse primers (Life technologies, USA): forward: 5'TGCCATCAAGGATAGGCAAG-3'; reverse: $5 '-$ AATGCTGCAAAATGGCACAC-3'.

PCR reactions were carried out in a Perkin-Elmer 9600 thermal cycler starting with heating at $95{ }^{\circ} \mathrm{C}$ for $4 \mathrm{~min}$ then using melting, annealing, and extension cycling conditions of $94^{\circ}$ for $1 \mathrm{~min}, 60^{\circ}$ for $1 \mathrm{~min}$, and $72^{\circ}$ for 2 min respectively. All amplifications were carried out for 30 cycles followed by final extension time at $75^{\circ} \mathrm{C}$ for 4 min. All reactions were conducted with $\beta$-actin primers (790 bp) as internal controls (5'primer: 5'TGA CGG GGT CAC CCA CAC TGT GCC CAT CTA 3', 3'primer: 3'CTA GAA GCA TTT GCG GTG GAC GAT GGA GGG. 5', Stratagene).

An aliquot of $20 \mu \mathrm{l}$ from each amplified cDNA product (356 bp) was separated on $2 \%$ agarose gel (Sigma), and visualized by UV light illuminator using ethidium bromide staining and photographed by Polaroid film. The intensity of bands was quantified by gel proanalyzer image analyzer version III where the area of a selected band was blotted against calibration curve of a single image using multiple standard bands to give the band amount in nanograms (ng) and the results were analyzed by this computer software (Biorad, UK) (Fig. 1).

Statistical analysis

All the values are expressed as mean \pm SD. Statistical analyses were performed using Student " $t$ " test for comparing two groups. When comparing more than 2 groups, oneway analysis of variance followed by Tukey's post hoc test (multiple comparisons) was performed. A spearman rank correlation was performed to determine the correlation between the studied parameters. A pvalue $<0.05$ was considered significant. SPSS version 10.0 was used for all statistical analysis.

\section{RESULTS}

Body weight, plasma glucose levels, Lipid profile, hepatic enzyme activities and $\beta$-Hydroxybutyrate

Table (1) summarizes the mean changes in body weights, plasma glucose levels, lipid profile, hepatic enzyme activities and $\beta$-HB in all the studied groups. Before the commencement of this study, all the groups had similar body weight, comparable levels of plasma glucose and lipid profiles (data not shown).

After STZ administration, rats demonstrated the typical characteristics of type 1 diabetes such as increase in food and water intake, polyuria (data not shown), the body weights were significantly decreased and the plasma glucose level as well as serum cholesterol, triglyceride concentrations were significantly increased in diabetic rats (G-II), when compared to control rats (G-I).

Administration of melatonin (GIII), or taurine (G-IV) significantly alleviated the hyperlipidemia, and restored the body weight slightly nonsignificantly as compared to G-I (but higher body weight than that of diabetes group (G-II)), but as regards plasma glucose, melatonin induce an insignificant changes, however taurine induce significant decrease in plasma glucose level as compared to G-II 
with still significant differences with G-I.

Of notice, STZ-induced diabetes caused an increase in the ALT, AST activities in the serum, and in plasma $\beta$-HB level . However, melatonin or taurine supplementation not only reduced the ALT and AST serum levels but also, significantly reduced plasma $\beta$-HB (with marked decrease in G-IV than in G-III) . (Table 1)

Oxidative stress

Table 2 shows that plasma AOPP and liver MDA (oxidative stress markers), were significantly elevated in G-II compared with G-I. Melatonin or taurine decreased significantly their levels as compared with G-II, with no significant differences as compared with G-I, while serum PON1 and hepatic GPx were significantly decreased in G-II as compared with the control, melatonin or taurine caused significant increase in serum PON1 activities (with marked increase in G-IV), but only taurine treatment can elevate liver GPx to near normal, with no significant effect for melatonin..

\section{Catalytic activity and expression of} CYP2E1

In table (2) liver microsomes CYP2E1 activities in diabetic rats were significantly higher than those in non-diabetic rats. Taurine or melatonin supplementation in diabetic rats caused significant decrease in
CYP2E1 activity in liver microsomes as compared with G-II with no significant differences for taurine supplementation, but still significant differences for melatonin supplementation when compared with the G-I

A significant correlation exists not only between CYP2E1 activities and gene expression but also between both CYP2E1 activities and gene expression and the studied parameters. (Table 3)

The expression of CYP2E1 in different studied groups is represented in figure 1and 2. Similar to the results of enzyme activity, there were significant differences between all the studied groups except between G-I and G-IV with $(\mathrm{F}=23.1, \mathrm{P}<0.0001)$, in which hepatic CYP2E1 mRNA expression in untreated diabetic rats $(22.9 \pm 4.8 \mathrm{ng})$ was significantly increased $(\mathrm{P}<0.001)$ as compared to non-diabetic control (13.4 $\pm 0.9 \mathrm{ng})$. Melatonin and taurine supplementation in diabetic rats caused significantly decreased in hepatic CYP2E1 mRNA $(17.7 \pm 2.3 \mathrm{ng}$ vs. $\quad 14.2 \pm 1.8 \mathrm{ng}$, respectively) compared to levels in untreated diabetic rats but with more significant decrease $(\mathrm{P}<0.001)$ in taurine than in melatonin (Fig.2).

Histopathological pictures of the liver: are presented in fig 3 from A to $\mathrm{E}$ 
Table (1): comparison between the studied groups as regards body weight, fasting plasma glucose, lipid profile, hepatic enzyme activities and level of $\beta$ Hydroxybutyrate

\begin{tabular}{|c|c|c|c|c|c|}
\hline Parameter & $\begin{array}{l}\text { G-I } \\
(n=10)\end{array}$ & $\begin{array}{l}\text { G-II } \\
(n=10)\end{array}$ & $\begin{array}{l}\text { G-III } \\
(n=10)\end{array}$ & $\begin{array}{l}\text { G-IV } \\
(n=10)\end{array}$ & $\mathbf{P}$ \\
\hline $\begin{array}{l}\text { Final body weight } \\
\text { (g) }\end{array}$ & $152.0 \pm 18$ & $95.0 \pm 21^{a}$ & $116.3 \pm 18.2^{\mathrm{a}}$ & $115.5 \pm 17^{a}$ & $\begin{array}{l}\mathrm{p}<0.001 \text { All are sign except } \\
\text { IIvs.III, II vs. IV and III vs. IV }\end{array}$ \\
\hline $\begin{array}{l}\text { Final fasting plasma } \\
\text { glucose level (mg/dl) }\end{array}$ & $101.0 \pm 11$ & $300.0 \pm 20^{a}$ & $285.4 \pm 10.5^{\mathrm{a},}$ & $180.7 \pm 15.2^{\mathrm{a}, \mathrm{b}}$ & $\begin{array}{l}\mathrm{p}<0.001 \text { All are sign except } \\
\text { IIIvs.II, }\end{array}$ \\
\hline Triglyceride (mg/dl) & $123.2 \pm 19.7$ & $145.8 \pm 15.8^{a}$ & $122.6 \pm 21.1^{b}$ & $118.8 \pm 17.9^{b}$ & $\begin{array}{l}\mathrm{p}<0.001 \text { All are sign except } \\
\text { Ivs.III, I vs. IV and III vs. IV }\end{array}$ \\
\hline $\begin{array}{l}\text { Total cholesterol } \\
(\mathrm{mg} / \mathrm{dl})\end{array}$ & $79.4 \pm 12.8$ & $122.7 \pm 24.8^{\mathrm{a}}$ & $92.7 \pm 14.9^{b}$ & $82.3 \pm 6.1^{b}$ & $\begin{array}{l}\mathrm{p}<0.001 \text { All are sign except } \\
\text { Ivs.III, I vs. IV and III vs. IV }\end{array}$ \\
\hline $\mathbf{A L T}(\mathbf{U} / \mathbf{l})$ & $30 \pm 2$ & $40 \pm 3^{a}$ & $34 \pm 5^{b}$ & $31 \pm 3^{b}$ & $\begin{array}{l}\mathrm{p}<0.001 \text { All are sign except } \\
\text { Ivs.III, and I vs. IV }\end{array}$ \\
\hline $\mathbf{A S T}(\mathbf{U} / \mathbf{l})$ & $35 \pm 3$ & $50 \pm 4^{a}$ & $39 \pm 4^{b}$ & $38 \pm 3^{b}$ & $\begin{array}{l}\mathrm{p}<0.001 \text { All are sign except } \\
\text { Ivs.III, and I vs. IV and III vs. } \\
\text { IV }\end{array}$ \\
\hline $\begin{array}{l}\text { B-Hydroxybutyrate } \\
\text { (mmol/l) }\end{array}$ & $0.7 \pm 0.2$ & $4.5 \pm 0.3^{\mathrm{a}}$ & $2.9 \pm 0.3^{\mathrm{a}, \mathrm{b}}$ & $1.8 \pm 0.4^{\mathrm{a}, \mathrm{b}}$ & $\mathrm{p}<0.001$. all groups are sign \\
\hline
\end{tabular}

Values are expressed as mean $\pm \mathrm{SD}$, for ten animals in each group. G-I= control group

$\mathrm{G}-\mathrm{II}=$ untreated STZ induced diabetic group

$\mathrm{G}-\mathrm{III}=$ melatonin treated diabetic group $\mathrm{G}-\mathrm{VI}=$ taurine treated diabetic group

a Significantly different from the control group $(\mathrm{p}<0.05)$. b Significantly different from the

STZ treated group $(\mathrm{p}<0.05)$.

Table (2): comparison between the studied groups as regards oxidative stress parameters and hepatic CYP2E1 activities .

\begin{tabular}{|c|c|c|c|c|c|}
\hline Parameter & $\begin{array}{l}\text { G-I } \\
(n=10)\end{array}$ & $\begin{array}{l}\text { G-II } \\
(n=10)\end{array}$ & $\begin{array}{l}\text { G-III } \\
(n=10)\end{array}$ & $\begin{array}{l}\text { G-IV } \\
(n=10)\end{array}$ & $\mathbf{P}$ \\
\hline Plasma AOPP $(\mu \mathrm{mol} / \mathrm{l})$ & $24.4 \pm 4.2$ & $30.3 \pm 6.2^{\mathrm{a}}$ & $24.7 \pm 4.4^{b}$ & $24.9 \pm 2.1^{b}$ & $\begin{array}{l}\mathrm{p}<0.01 \text { All are sign except } \\
\text { Ivs.III, and I vs. IV and III } \\
\text { vs. IV }\end{array}$ \\
\hline $\begin{array}{l}\text { Serum PON } 1 \text { activity } \\
(\mathrm{nmol} / \mathrm{min} / \mathrm{ml})\end{array}$ & $13.6 \pm 3.1$ & $6.9 \pm 2.5^{a}$ & $15.1 \pm 2.5^{b}$ & $14.2 \pm 2.8^{b}$ & $\begin{array}{l}\mathrm{p}<0.001 \text { All are sign except } \\
\text { Ivs.III, and I vs. IV and III } \\
\text { vs. IV }\end{array}$ \\
\hline $\begin{array}{l}\text { Liver MDA (nmol/g. } \\
\text { tissue) }\end{array}$ & $23.6 \pm 3.1$ & $31.6 \pm 5.5^{\mathrm{a}}$ & $24.3 \pm 3.8^{b}$ & $23.9 \pm 2.8^{b}$ & $\begin{array}{l}\mathrm{p}<0.001 \text { All are sign except } \\
\text { Ivs.III, and I vs. IV and III } \\
\text { vs. IV }\end{array}$ \\
\hline $\begin{array}{l}\text { Liver GPx activity (nmol } \\
\text { of NADPH } \\
\text { oxidized } / \mathrm{min} / \mathrm{mg} \text { ) }\end{array}$ & $7.9 \pm 1.1$ & $4.8 \pm 1.1^{a}$ & $5.8 \pm 1.4^{a}$ & $6.5 \pm 1.5^{b}$ & $\begin{array}{l}\mathrm{p}<0.001 \text { All are sign except } \\
\text { I vs. IV, and II vs III. and } \\
\text { III vs. IV }\end{array}$ \\
\hline $\begin{array}{l}\text { Hepatic CYP2E1 } \\
\text { activities ( nmol/min/mg } \\
\text { protein) }\end{array}$ & $2.1 \pm 0.6$ & $5.2 \pm 1.6^{\mathrm{a}}$ & $3.5 \pm 0.7^{\mathrm{ab}}$ & $2.7 \pm 0.8^{b}$ & $\begin{array}{l}\mathrm{p}<0.001 \text { All are sign except } \\
\text { I vs .IV, and III vs. IV }\end{array}$ \\
\hline
\end{tabular}

Values are expressed as mean $\pm \mathrm{SD}$, for ten animals in each group.

G-I= control group $\quad \mathrm{G}-\mathrm{II}=$ untreated STZ induced diabetic group

$\mathrm{G}-\mathrm{III}=$ melatonin treated diabetic group

$\mathrm{G}-\mathrm{VI}=$ taurine treated diabetic group

a Significantly different from the control group $(\mathrm{p}<0.05)$. b Significantly different from the

STZ treated group $(\mathrm{p}<0.05)$. 
Table (3): correlation between hepatic CYP2E1 activities, gene expression and other studied parameters in diabetic groups $(n=30)$

\begin{tabular}{|c|c|c|c|c|}
\hline \multirow[t]{2}{*}{ Variables } & \multicolumn{2}{|c|}{$\begin{array}{l}\text { Hepatic CYP2E1 activities } \\
\text { ( } \mathrm{nmol} / \mathrm{min} / \mathrm{mg} \text { protein) }\end{array}$} & \multicolumn{2}{|c|}{$\begin{array}{l}\text { CYP2E1 gene } \\
\text { expression }\end{array}$} \\
\hline & $\mathbf{r}$ & $\mathbf{p}$ & $\mathbf{r}$ & $\mathbf{p}$ \\
\hline$\beta$-Hydroxybutyrate (mmol/l) & 0.49 & $<0.001$ & $\mathbf{0 . 5 0}$ & $<0.001$ \\
\hline Plasma AOPP $(\mu \mathrm{mol} / \mathrm{l})$ & 0.37 & $<0.05$ & $\mathbf{0 . 4 0}$ & $<0.05$ \\
\hline Serum PON 1 activity $(\mathrm{nmol} / \mathrm{min} / \mathrm{ml})$ & -0.40 & $<0.05$ & 0.43 & $<0.05$ \\
\hline Liver MDA (nmol/g. tissue) & 0.39 & $<0.05$ & 0.45 & $<0.01$ \\
\hline $\begin{array}{l}\text { Liver GPx activity (nmol of NADPH } \\
\text { oxidized } / \mathrm{min} / \mathrm{mg} \text { ) }\end{array}$ & -0.42 & $<0.05$ & 0.48 & $<0.001$ \\
\hline $\begin{array}{l}\text { Hepatic CYP2E1 activities } \\
\text { ( nmol/min/mg protein) }\end{array}$ & --------- & ---------- & 0.50 & $<0.001$ \\
\hline
\end{tabular}
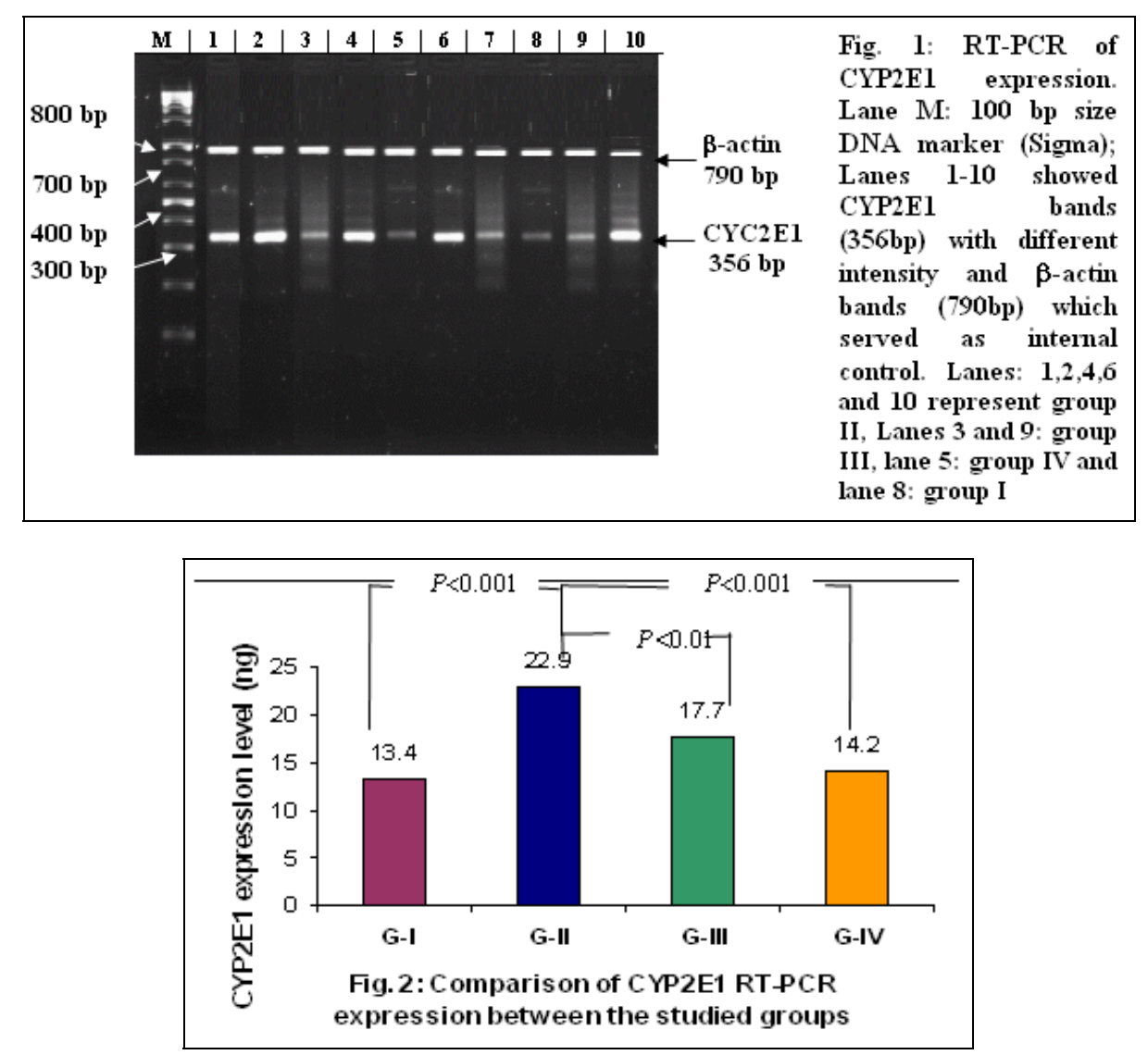

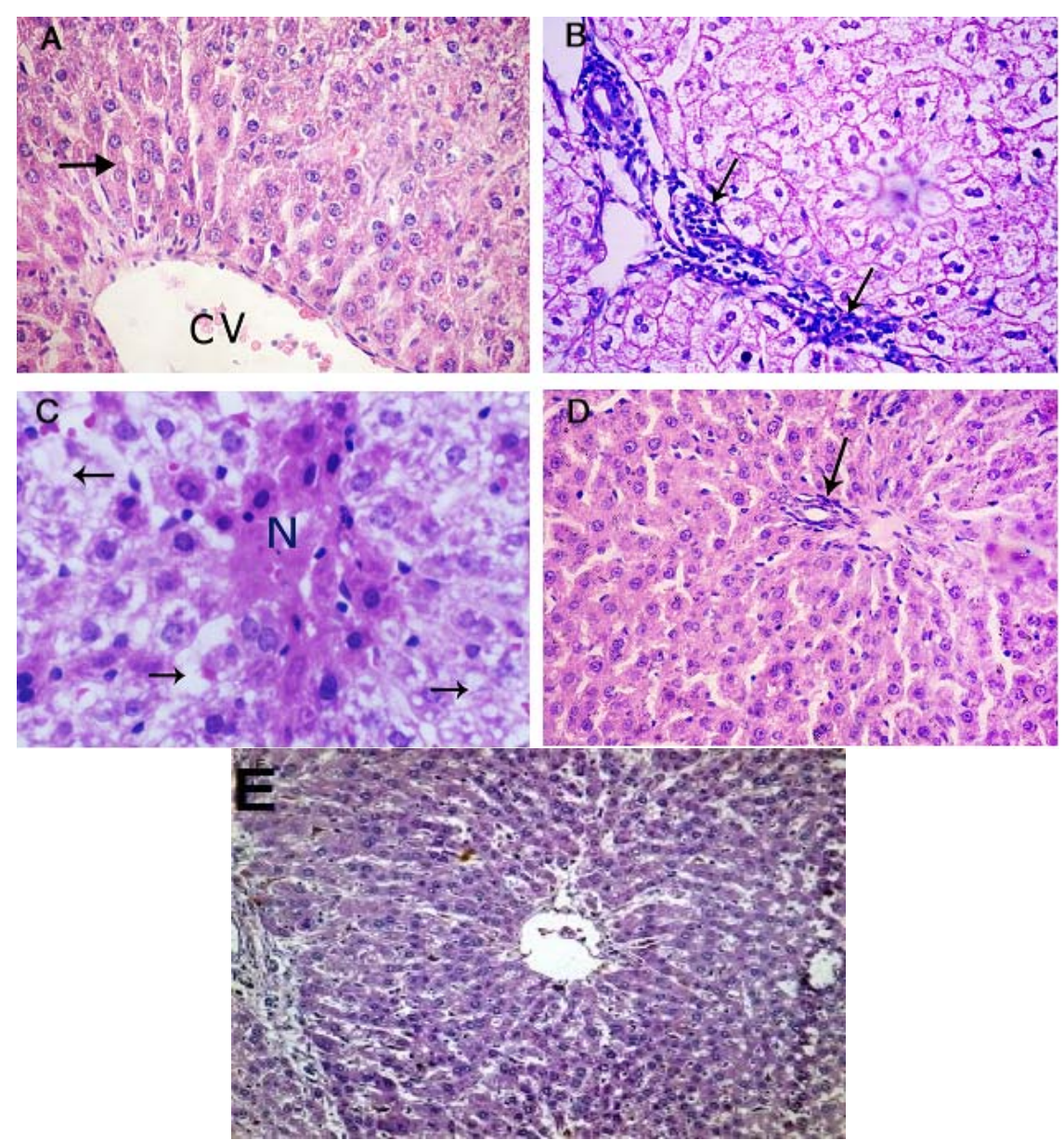

Fig. 3: Light microscopical photomicrograph of liver tissue of control group (A) showing the normal hepatocytes with rounded nuclei forming hepatic cell cords $(\rightarrow$ ) radiating from the central vein $(\mathrm{CV})$, liver tissue of diabetic rat (B) showing the hypertrophied and vacuolated hepatic cells and the heavy cellular infiltration $(\rightarrow)$ and (C) shows small areas of focal necrosis and vacuolated hepatocytes. Liver tissue of diabetic rat (D) treated with taurine, treated with melatonin (E) showing the apparently normal hepatic cells with few inflammatory cells around a blood vessel $(\rightarrow)(H \&$ E. Mag. x 400). 


\section{DISCUSSION}

Both human and experimental animal models of diabetes exhibit high oxidative stress due to persistent and chronic hyperglycemia which depletes the activity of free radical scavenging enzymes and thus promotes free radicals generation. In recent years, it has been shown that dietary supplementation with natural antioxidants attenuated the oxidative stress and diabetic state induced by STZ. ${ }^{(7,22)}$

In the present study, in STZ induced diabetic rats, decreased body weight and increased plasma glucose level were observed, neither melatonin nor taurine were able to prevent weight loss, but taurine has the capability to return plasma glucose to near normal level which may be due to diminished rate of renal gluconeogenesis $^{(23)}$, inhibition of oxidative stress ${ }^{(24)}$ or due to the potentiation of the effects of insulin $^{(\mathbf{2 5})}$. These findings indicate that taurine is involved in distinct processes necessary for the control of glucose homeostasis. On the other hand, melatonin did not significantly prevent the development of hyperglycaemia in the STZ-induced diabetic rats similar to the results of other researchers. ${ }^{(26,27)}$

The present study revealed marked increases in serum triglycerides, total cholesterol and liver enzymes in STZ-induced diabetic rats, but treatment of the diabetic rats with either melatonin or taurine resulted in marked decrease in serum lipids and liver enzymes with more decrease in taurine treated group, which may be due to upregulation of hepatic LDL receptor and/or through improving the binding of LDL to them. ${ }^{(28)}$

In the current study, elevated liver MDA levels in STZ induced diabetic rat was demonstrated, similar to previous studies. ${ }^{(\mathbf{2 9 , 3 0})}$ The reduced MDA levels after melatonin or taurine treatment could be related to their direct anti-oxidant effects through their direct scavenging action. ${ }^{(23,31)}$ It has been suggested that taurine stabilizes biomembranes and attenuate tissue lipid peroxidation. ${ }^{(32)}$ Because lipids are substrates for lipid peroxidation, a decrement in serum triglyceride levels could be another contributing factor to the reduced MDA levels under melatonin or taurine treatment. ${ }^{(8)}$

In the current study the significant higher plasma AOPP levels reported in untreated diabetic rats came in agreement with those of Kalousova et $a l^{(\mathbf{3 3})}$ but upon melatonin or taurine treatment, AOPP formation could decrease and this came in accordance with the studies of Eskiocak et al. and Kilic, and Yildirim ${ }^{(34,35)}$

The high level of lipid peroxidation marker, in the diabetic rats is a reflection of insufficiency of antioxidant defenses in combating ROS-mediated damage. ${ }^{(36)}$ In this study, the hepatic GRx activity was decreased in the diabetic tissues which may be due to hyperglycemia ,leading to glycation of antioxidant enzymes causing its inactivation. ${ }^{(10)}$ Furthermore, Andallu et al., ${ }^{(37)}$ reported that the decreased activities of SOD, CAT and GPx in diabetic rats 
could be due to increased utilization for scavenging free radicals. In the present study, taurine increased the hepatic GPx activity which came in accordance with Franconi et al., ${ }^{(32)}$ since cysteine is a precursor of taurine and GSH, taurine supplementation may cause enhancement in GSH levels by directing cysteine into the GSH synthesis pathway. Therefore, increased GSH levels after taurine treatment may play an additional role in decreasing oxidative stress, but melatonin has no significant effect and this came in accordance with the result of Oktem et al. ${ }^{(38)}$

It was reported previously that PON1 activity was reduced in several situations associated with oxidative stress ${ }^{(39)}$. In the present study, PON1 was significantly lowered in diabetic rats, which might be related to increased lipid peroxide levels and/or glycation of HDL which may increase its turnover and reduce its efficiency. Inoue et al. ${ }^{(\mathbf{4 0 )}}$ reported that there are some inhibitors against PON1 activity in circulating blood of diabetic patients such as glycosylated proteins. Reduced PON1 activity was suggested to play a role in the severity of coronary atherosclerosis, especially in diabetics, and low concentration and enzymatic activity of PON1 were thought to be independent predictors of cardiovascular events in diabetic patients. ${ }^{(\mathbf{4 1 , 4 2})}$

In the present study, it was observed that taurine or melatonin supplementation increased serum PON1 activities in STZ induced diabetes in rats which came in agreement with Dirican et al., ${ }^{(43)}$, Tas et al., ${ }^{(44)}$ and El Mesallamy et al. ${ }^{(45)}$ Because lipid peroxidation products have been reported to inhibit PON1 activity, the reduced tissue MDA levels, which reflected an improvement in the oxidative- antioxidative balance, may be a contributing factor to the increased serum PON1 activities. ${ }^{(46)}$ This effect may be one of the antiatherosclerotic activities of taurine, so, taurine supplementation may be beneficial for diabetic patients with decreased PON1 activity to make them less susceptible to coronary heart diseases. However, further investigations on the effect of taurine supplementation in healthy and diabetic humans are needed to support this suggestion. Topsakal et al., (47) reported that melatonin may play a role in increasing the reduced PON concentrations by improving the glucose metabolism and/or oxidative stress.

CYP2E1 is inducible in several patho-physiological states including diabetes and its expression parallels increased ROS production and oxidative stress in various tissues of STZ-induced diabetes rats. ${ }^{(5)}$ In the current study, both the hepatic CYP2E1 enzyme activity and gene expression, were increased in STZinduced diabetic rats as compared with control and both were significantly correlated with the studied oxidative stress parameters and with $\beta$-Hydroxybutyrate.

The present study supported previous observations on the CYP2E1-dependent liver injury in STZ-induced diabetic rats. ${ }^{(48)}$ This link stems from the unusually high capacity of CYP2E1 to generate free radicals which are thought to result in lipid peroxidation and thus contribute 
to liver disease. ${ }^{(49)}$ Diabetes is commonly associated with the development of nonalcoholic steatohepatitis. Therefore, it is possible that the increased expression of CYP2E1 can lead to liver disease in diabetics. $^{(50)}$ Also, it has been suggested that the increased ketones and other small organic molecules in diabetes act as inducers of CYP2E1. Although the mechanism is not fully understood, it may be related to an enhanced rate of gene transcription. ${ }^{(51)}$

The current study, further demonstrated that the production of CYP2E1 both gene expression and enzyme activity can be prevented not only by taurine but also by melatonin supplementation, which is less than that of taurine so, they can protect the liver from the hepatic injury induced by type 1 diabetes. In correlation with these, this study showed that elevated levels of ketone bodies ( $\beta$-HB) by STZ are reduced by taurine more than melatonin supplementation, so that the suppression of ketone production can be one of the mechanisms of a reduction in CYP2E1 gene expression in diabetic rats. These results came in agreement with Yao et al., ${ }^{(11)}$ who showed that taurine supplementation caused a significant decrease in plasma $\beta$-HB levels in diabetic rats compared with untreated diabetic animals. Also, they concluded that the diabetes-induced CYP2E1 expression was down regulated by taurine, and the amounts of reduction of enzyme activities in the liver and kidneys were approximately parallel to the reduction of plasma concentrations of $\beta$-HB in diabetic rats after taurine treatment. Furthermore, the exact mechanism of inhibition of diabetes- induced CYP2E1 elevation by taurine warrants further studies.

Finally in the present study, the hepatic protective role of melatonin and taurine in STZ-induced diabetic liver damage was established by normalization of hepatic histological picture upon treatment of STZ induced diabetes by either taurine or melatonin.

\section{CONCLUSION}

Adverse hepatic events associated with Type I diabetes may be a result of enhanced CYP2E1 gene expression and enzyme activity which may be due to increased oxidative stress or $\beta$ Hydroxybutyrate activity . Taurine has the capabilities more than melatonin in protecting the liver from the hepatic injury induced by type 1 diabetes, by either reducing the oxidative stress, or restoring CYP2E1 activity and gene expression. Therefore antioxidants might prove beneficial as an adjuvant treatment to insulin in type 1 diabetes associated with manifestations of liver injury.

\section{Acknowledgements}

The authors thank Dr Abdel Razek Sheta, Department of Anatomy, Faculty Of Medicine, Tanta University, Egypt, for his performance of the histopathology of the liver samples

\section{REFERENCES}

1. Niedowicz DM, and Daleke DL (2005): The role of oxidative stress in diabetic complications. Cell Biochem. Biophys.,43(2): 289-330 
2. Piconi L, Quagliara $L$ and Ceriello A (2003): Oxidative stress in diabetes. Clin. Chem. Lab. Med.,41(9):1144-9

3. Damasceno DC, Volpato GT, Paranhos-Calderon $M$ and Cunha-Rudge MV (2002): Oxidative stress and diabetes in pregnant rats. Anim. Reprod. Sci., 72(3-4): 235-44.

4. Kume E, Fujimura H, Matsuki N, Ito M, Aruga C Toriumi W, Kitamura $K$ and Doi K (2004): Hepatic changes in the acute phase of streptozotocin (SZ)induced diabetes in mice. Exp. Toxicol. Pathol., 55(6): 467-80.

5. Ahn T, Yun $C H$ and $O h$ DB (2006): Tissue-specific effect of ascorbic acid supplementation on the expression of cytochrome P450 2E1 and oxidative stress in streptozotocin-induced diabetic rats. Toxicol. Lett., 166(1) :2736.

6. El-Serag HB, Tran T, and Everhart JE (2004): Diabetes increases the risk of chronic liver disease and hepatocellular carcinoma. Gastroenterology 126(2):460-8.

7. Coskun O, Kanter M, Korkmaz $A$ and Oter S (2005): Quercetin, a flavonoid antioxidant, prevents and protects streptozotocininduced oxidative stress and $\beta$ cell damage in rat pancreas. Pharmacol. Res., 51(2): 117- 23.

8. Manna P, Das J, Ghosh J, Sil PC (2010): Contribution of type 1 diabetes to rat liver dysfunction and cellular damage via activation of NOS, PARP, IkappaBalpha/NF-kappaB,

MAPKs, and mitochondria- dependent pathways:

Prophylactic role of arjunolic acid. Free Radic Biol Med. ;48(11):1465-84

9. Balkan J, Kanbali O, AykaToker $G$ and Uysal $M$ (2002): Taurine treatment reduces hepatic lipids and oxidative stress in chronically ethanol-treated rats. Biol. Pharm. Bull.,25 (9):1231-3.

10. Yavuz O, Cam M, Bukan N, Guven A, and Silan F (2003): Protective effect of melatonin on $\beta$-cell damage in streptozotocininduced diabetes in rats. Acta Histochemica; 105(3):261-6.

11. Yao HT, Lin P, Chang YW, Chen CT, Chiang MT, Chang L, Kuo YC and Tsai HT (2009): Effect of taurine supplementation on cytochrome P450 2E1 and oxidative stress in the liver and kidneys of rats with streptozotocin-induced diabetes. Food Chem. Toxicol.,47 (7):1703-9.

12. Montilla PL, Vargas JF, Túnez IF, Muñoz de Agueda MC, and Cabrera ES (1998): Oxidative stress in diabetic rats induced by streptozotocin: protective effects of melatonin. J. Pineal Res.,25(2):94-100

13. González-Jasso E, López T, Lucas D, Berthou F, Manno M, Ortega A, Albores A(2003). CYP2E1 regulation by benzene and other small organic chemicals in rat liver and peripheral lymphocytes. Toxicol Lett. ;144(1):55-67.

14. McGarry JD, Guest MJ and Foster DW (1970): Ketone body metabolism in the ketosis of 
starvation and alloxan diabetes. J. Biol. Chem. 245(17): 4382-90.

15. Witko-Sarsat V, Friedlander M, Capeillère-Blandin C, Nguyen-Khoa T, Nguyen AT, Zingraff J, Jungers $P$, and Descamps-Latscha B (1996): Advanced oxidation protein products as a novel marker of oxidative stress in uremia. Kidney Int.,49(5):1304-13

16. Mackness B, Mackness MI, Arrol S, Turkie W, Julier K, Abuasha B, Miller JE and Durrington PN (1998): Serum paraoxonase (PON-1) 55 and 192 polymorphism and paraoxonase activity and concentration in noninsulin dependent diabetes mellitus.

Atherosclerosis, 139(2):341-9.

17. Halliwell $B$ and Chirico $S$. (1993): Lipid peroxidation: its mechanism, measurement, and significance. Am. J. Clin. Nutr., 57(5 Suppl):715S-724S; discussion $724 \mathrm{~S}-725 \mathrm{~S}$

18. Flohe $L$ and Gunzler WA (1984): Assays for glutathione peroxidase. Methods Enzymol., 105: 114-21.

19. Reinke, L.A., Moyer, M.J., (1985): p-Nitrophenol hydroxylation: a microsomal oxidation which is highly inducible by ethanol. Drug Metab. Dispos. 13(5), 548-552

20. Lowry $O$, Rosebrough $N$ and Ranadall $R$ (1951): Protein measurement with the folin phenol reagent. J. Biol. Chem., 193(1): 265-9.

21. Yang SP and Raner GM (2005): Cytochrome P450 expression and activities in human tongue cells and their modulation by green tea extract. Toxicol. Appl. Pharmacol., 15;202 (2):140-50.

22. Simmons RA (2006): Developmental origins of diabetes: the role of oxidative stress. Free Radic. Biol. Med., 40(6): 917-22.

23. Winiarska K, Szymanski K, Gorniak P, Dudziak $M$ and Bryla J (2009): Hypoglycaemic, antioxidative and nephroprotective effects of taurine in alloxan diabetic rabbits. Biochimie, 91(2):261-70.

24. Verzola D, Bertolotto MB, Villaggio B, Ottonello L, Dallegri F, Frumento G, Berruti V, Gandolfo MT, Garibotto $G$ and Deferran $G$ (2002): Taurine prevents apoptosis induced by high ambient glucose in human tubule renal cells. J. Investig. Med.,50(6):443-51.

25. Cherif H, Reusen B, Ahn MT, Hoet JJ and Remacle C (1998): Effects of taurine on the insulin secretion of rat foetal islets from dams fed a low protein diet. J. Endocrinol., 159(2):341-8.

26. Vural H, Sabuncu T, Arslan SO, and Aksoy N (2001): Melatonin inhibits lipid peroxidation and stimulates the antioxidant status of diabetic rats. J. Pineal Res. ;31(3):193-8

27. Guven A, Yavuz O, Cam M, Ercan F, Bukan N, Comunoglu $C$ and Gokce $F$ (2006): Effects of melatonin on streptozotocininduced diabetic liver injury in rats. Acta Histochem.,108 (2):8593. 
28. Yang SF, Tzang BS, Yang KT, Hsiao YC, Chang YY, Chan CH, Fu SG and Chen YC (2010): Taurine alleviates dyslipidemia and liver damage induced by a high fat/ cholesterol-dietary habit. Food Chemistry, 120(1):156-62.

29. Halliwell B (2000): Lipid peroxidation, antioxidants and cardiovascular disease: how should we more forward? Cardiovasc. Res., 47(3): 410-8

30. Brownlee M (2001): Biochemistry and molecular cell biology of diabetic complications. Nature, 414(6865):813-20

31. Reiter RJ, Tan DX, Osuna C and Gitto $E$ (2000): Actions of melatonin in the reduction of oxidative stress. A review. J. Biom. Sci.,7(6): 444-58.

32. Franconi F, Di Leo MA, Bennardini $F$ and Ghirlanda $G$ (2004): Is taurine beneficial in reducing risk factors for diabetes mellitus. Neurochem. Res., 29(1): 143-50.

33. Kalousova $M$, Skrha $J$ and Zima T (2002): Advanced glycation endproducts and advanced oxidation protein products in patients with diabetes mellitus. Physiol Res.,51(6):597604.

34. Eskiocak S, Tutunculer F, Basaran UN and Taskiran A (2007): The effect of melatonin on protein oxidation and nitric oxide in the brain tissue of hypoxic neonatal rats. Brain Dev. 29(1):19-24.

35. Kilic, $N$ and Yildirim $Z$ (2008): Effects of Taurine and Age on Liver Antioxidant Status and
Protein Oxidation. Turk J Biochem; 33 (4) ; 169-174

36. Palsamy $P$, Sivakumar $S$ and Subramanian S (2010): Resveratrol attenuates hyperglycemia-mediated oxidative stress, proinflammatory cytokines and protects hepatocytes ultrastructure in streptozotocin-nicotinamideinduced experimental diabetic rats. Chem. Biol. Interact. 30; 186 (2):200-10.

37. Andallu B and Varadacharyulu NC (2003): Antioxidant role of mulberry (Morus Indica L.) leaves in streptozotocin diabetic rats. Clinica Chimica Acta., 338(1-2):3-10.

38. Oktem F, Ozguner F, Yilmaz HR, Uz E, Dündar B.(2006): Melatonin reduces urinary excretion of N-acetyl-beta-Dglucosaminidase, albumin and renal oxidative markers in diabetic rats. Clin Exp Pharmacol Physiol. ;33(1-2):95-101.

39. Mohamed RH, Mohamed RH, Karam RA and Abd El-Aziz TA (2010): The relationship between paraoxonase1-192 polymorphism and activity with coronary artery disease. Clin. Biochem.,43 (6):553-8.

40. Inoue M, Suehiro T, Nakamura $T$ and Ikeda $Y$ (2000): Serum arylesterase/ diazoxonase activity and genetic polymorphism in patients with type II diabetes. Metabolism; 49(11):1400-5.

41. Tartan Z, Orhan G, Kasıkcioglu H, Uyarel H, Unal S, Ozer N, Ozay B, Ciloglu, F and Cam N (2007): The role of paraoxonase (PON) enzyme in 
the extent and severity of the coronary artery disease in type- 2 diabetic patients. Heart Vessels, 22(3):158-64.

42. Ikeda $Y$, Inoue M, Suehiro T, Arii $\mathrm{K}$, Kumon $\mathrm{Y}$ and Hashimoto K (2009): Low human paraoxonase predicts cardiovascular events in Japanese patients with type 2 diabetes. Acta Diabetol., 46(3):239- 42.

43. Dirican $M$, Taş $S$ and Sarandöl E (2007): High-dose taurine supplementation increases serum paraoxonase and arylesterase activities in experimental hypothyroidism. Clin Exp Pharmacol. Physiol., 34(9):833-7

44. Tas S, Sarandol E, Ayvalik SZ, Serdar $Z$ and Dirican $M$ (2007): Vanadyl sulfate, taurine, and combined vanadyl sulfate and taurine treatments in diabetic rats: effects on the oxidative and antioxidative systems. Arch. Med. Res., 38(3):276-83.

45. El Mesallamy HO, ElDemerdash E, Hammad LN and El Magdoub HM (2010): Effect of taurine supplementation on hyperhomocysteinemia and markers of oxidative stress in high fructose diet induced insulin resistance. Diabetol. Metab. Syndr., 30:2-46.

46. Aviram $M$, Rosenblat $M$ and Billecke S (1999): Human serum paraoxonase (PON1) is inactivated by oxidized low density lipoprotein and preserved by antioxidants. Free Radic. Biol. Med., 26(7-8): 892-904.

47. Topsakal C, Kilic N, Ozveren F and Akdemir I (2003): Effects of prostaglandin E1, melatonin, and oxytetracycline on lipid peroxidation, antioxidant defense system, paraoxonase (PON1) activities, and homocysteine levels in animal model of spinal cord injury. Spine; 28 (15):164352.

48. Raza H, Prabu SK, Robin MA and Avadhani RG (2004): Elevated mitochondrial cytochrome P450 2E1 and glutathione-S-transferase A4-4 in streptozotocin-induced diabetic rats: tissue specific variations and roles in oxidative stress. Diabetes 53(1):185-94.

49. Wang Z, Hall SD, Maya JF, Li L, Asghar A, Gorski JC(2003): Diabetes mellitus increases the in vivo activity of cytochrome $\mathrm{P} 450$ 2E1 in humans. $\mathrm{Br} \mathrm{J}$ Clin Pharmacol. 55(1):77-85.

50. Wu CW, Yu J(2010): Molecular basis for a functional role of cytochrome P450 2E1 in nonalcoholic steatohepatitis. J Gastroenterol Hepatol. 25(6):1019-20.

51. Dey A, Cederbaum AI (2007): Induction of cytochrome P450 2E1 [corrected] promotes liver injury in ob/ob mice. Hepatology. 45(6):1355-65. 


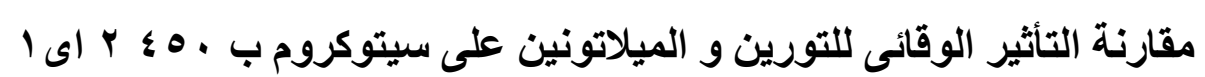

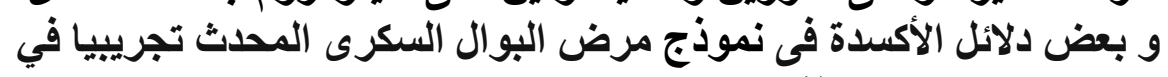

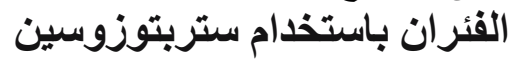

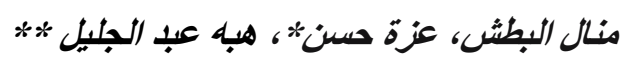

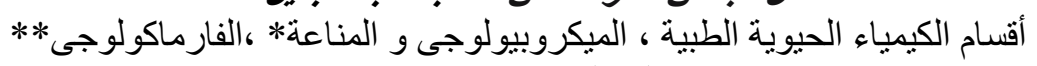
كلية الطب، جامعة طنطا

صممت هذه الدراسة لمعرفة الوقاية المحتملة للتورين و الميلاتونين ضد مرض البو ال السكرى المحدث تجريبيا

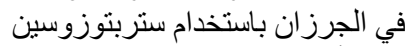

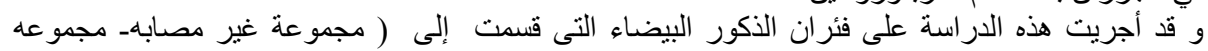

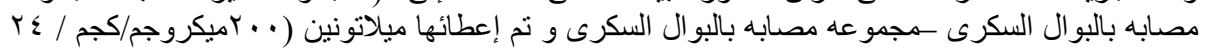

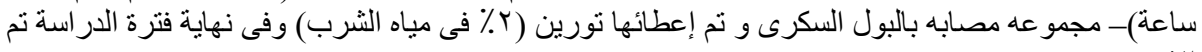

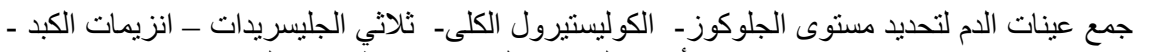

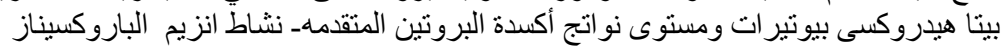

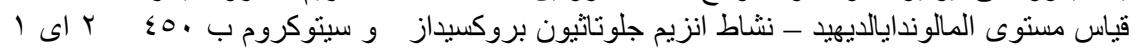

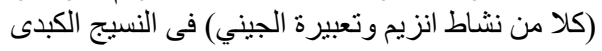

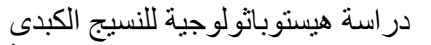

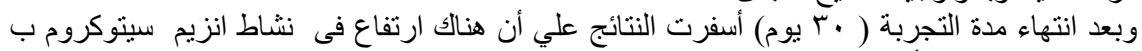
.

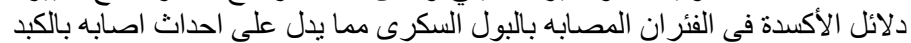

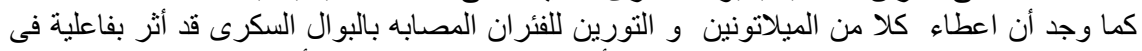

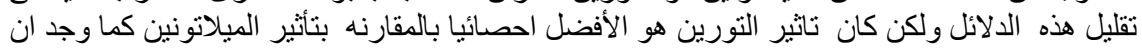

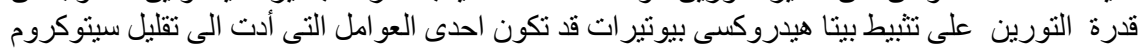

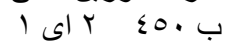

الاستتتاج ان اعطاء التورين أدي الى تاثير أفضل من تأثير الميلاتونين فى تقليل دلائل الأكسدة و تقليل نشاط

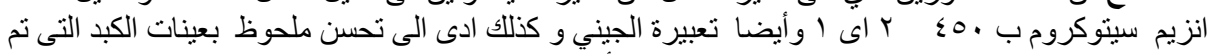

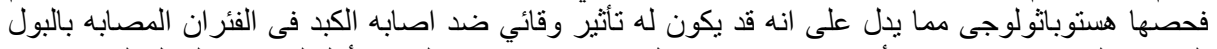

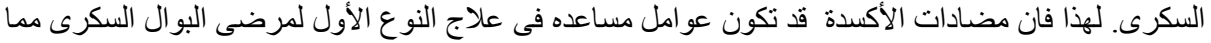
يؤدى الى تحسن اعر اض الهذ الاصنابه الكبديه المصاحبة له له 